\title{
A RETROSPECTIVE EVALUATION OF PATIENTS WITH NON ALARMING LOWER GASTROINTESTINAL SYMPTOMS AND COLONOSCOPIC FINDINGS OF ILEAL OR COLONIC ULCERATIONS AND HISTOPATHOLOGICAL EVIDENCE OF NONSPECIFIC COLITIS
}

\author{
Jeffey George1, Roopa Poulose 2 \\ ${ }^{1}$ Assistant Professor, Department of Gastroenterology, AIMS, Kochi, Kerala \\ 2Professor, Department of Pathology, AIMS, Kochi, Kerala.
}

\section{ABSTRACT}

\section{BACKGROUND}

The clinical course and treatment modalities for patients with non alarming lower gastrointestinal symptoms and colonoscopic findings of isolated or random ileal or colonic ulcerations which are histologically proven to be non-specific inflammation, are unknown.

\section{OBJECTIVE}

To evaluate the clinical course and significance of non-specific colonic inflammation in patients presenting with lower gastrointestinal symptoms of hypogastric or iliac fossa pain and altered bowel habits.

\section{DESIGN}

Single Centre Retrospective Analysis.

\section{SETTING}

Tertiary Care Referral Hospital.

\section{PATIENTS AND INTERVENTIONS}

All patients presenting with lower GI symptoms and who had colonoscopic evidence of isolated or random ileal or colonic ulcerations with histopathologic evidence of mild or active inflammation analysed by a single pathologist between January 2012 December 2012 were followed up either as outpatient visit or by telephonic interview. Patients with alarm symptoms, red flags, age more than 60 years and other co morbid illness were excluded.

\section{MAIN OUTCOME MEASUREMENTS}

The clinical courses of these patients were followed up for a mean period of 39 months.

\section{RESULTS}

Of the 31 patients who were included, 6 were lost to follow up. 19 patients were off medications and asymptomatic during the follow up. 2 patients were asymptomatic with mesalamine tablets and another asymptomatic patient had resorted to homeopathic medication. Of the two patients who were on mesalamine, one had endoscopic evidence of linear ulcerations in rectum and the second patient had peri appendiceal inflammation on colonoscopy, both of whom had mild or focal colitis histologically. 3 patients were symptomatic during the follow up but only on symptomatic medications on and off, of which one of them had aphthous ulcerations throughout the entire colon and the other had histologically active chronic ileitis.

\section{LIMITATIONS}

Retrospective data and a relatively short follow up and small patient number.

\section{CONCLUSIONS}

Majority of the patients with non-alarming lower GI symptoms had colonoscopic evidence of ileal or colonic ulcerations with non-specific mild chronic colitis on histology, resolved without evolution to inflammatory bowel disease on follow up.

\section{KEYWORDS}

Colitis, ileal Ulcer, Colonic Ulcer.

HOW TO CITE THIS ARTICLE: George J, Poulose R. A retrospective evaluation of patients with non alarming lower gastrointestinal symptoms and colonoscopic findings of ileal or colonic ulcerations and histopathological evidence of nonspecific colitis. J. Evolution Med. Dent. Sci. 2016;5(37):2213-2216, DOI: 10.14260/jemds/2016/514

Financial or Other, Competing Interest: None.

Submission 07-03-2016, Peer Review 20-04-2016,

Acceptance 26-04-2016, Published 07-05-2016.

Corresponding Author:

Jeffey George,

Assistant Professor,

Department of Gastroenterology,

AIMS, Kochi-682041,

Kerala.

E-mail: jeffeygeorge@gmail.com

DOI: $10.14260 /$ jemds $/ 2016 / 514$

\section{INTRODUCTION}

The natural history of patients presenting with gastrointestinal symptoms of abdominal pain and altered bowel habits without alarm signs and who have colonoscopic findings of isolated or random ileal and colonic ulcers is uncertain. The colonoscopic biopsies in this context are often reported by pathologists as nonspecific colitis. It is challenging in these situation to determine whether this cohort of patients will benefit by medications such as mesalamine. The challenging task for both the pathologist and clinician is to 
correctly exclude those patients presenting with symptoms of an index Crohn's disease. There are currently no guidelines available for management in these difficult cases. We therefore decided to analyse to determine the clinical significance and outcome in those patients with nonspecific colitis.

\section{PATIENTS AND METHODS}

This is a one year (January 2012 to December 2012) retrospective study of all patients who presented with lower symptoms and had random or isolated ileal or colonic ulcerations all of which histologically showed focal mild active or nonspecific chronic colitis. The study protocol was approved by the Institutional Review Board of our institution.

Patients were identified from electronic medical registry through computerized diagnostic codes. Ileal or colonic ulcerations were defined as definite mucosal breaks in the terminal ileum or any segment of colon.

Patients with hyperaemic lesions without mucosal breaks were not included. We excluded patients if they had (1) colonic symptoms of bleeding per rectum or weight loss; (2) a history of nonsteroidal anti-inflammatory drug (NSAID) usage in the recent 6 months (3) history of colorectal cancer or surgery of the colorectum; (4) coincidental ulcerative lesions in the ileocecal valve; (5) colonoscopic findings and histology confirming inflammatory bowel disease or tuberculosis.

All the colonoscopies were performed by staff gastroenterologists using standard videocolonoscopes. It was difficult to evaluate the colonoscopic findings precisely because of the retrospective study design. All cases were reviewed by a single GI pathologist. These patients were followed up either as outpatient visit or by telephonic interview for a mean period of 39 months. Statistical analyses were performed with SPSS software. Results were expressed as proportions or means and compared using the chi square test. $\mathrm{P}$ values of.05 were considered to be statistically significant.

\section{RESULTS}

\section{Study Population}

A total of 39 patients were identified from the database of which 31 were included as per study criteria. The mean follow up period was 39 months. $6 / 31$ (19.35\%) patients were lost to follow up, could not be contacted via telephone or mail. During the study period only one patient had a repeat colonoscopy due to persisting symptoms.

Demographics - Of the total 31 included patients, there were 22 males and 9 females. The mean age of the patients was 42.03 years (Range 20-60 years).

\section{Outcome}

These patients were assessed were followed up for a maximum of over 3 years. 2 patients were empirically put on mesalamine tablets with relief of symptoms. One of these patients had colonoscopic evidence of linear ulceration which was confirmed to be focally active proctitis. The other patient had periappendiceal inflammation with biopsy suggestive of mild active inflammation. One patient had resorted to homeopathic medication which gave relief of his symptoms. $3 / 31(9.68 \%)$ patients had reported to having continued symptoms on and off which was relieved by symptomatic medications. They were not on any continuous medications.
The rest $19 / 31$ (63.3\%) patients were reported to be asymptomatic. Follow up colonoscopies were not performed in the patients, hence the natural history of the colonic and ileal ulcerations could not be documented. The fact that follow up colonoscopies were not done could be justified as there were no pressing indications for the same.

\begin{tabular}{|c|c|c|c|c|}
\hline Sl. & Age & Sex & $\begin{array}{c}\text { Colonoscopy } \\
\text { Findings }\end{array}$ & Histopathology \\
\hline 1 & 26 & M & $\begin{array}{l}\text { Multiple ulcers } \\
\text { randomly } \\
\text { distributed } \\
\text { from caecum to } \\
\text { rectum, normal } \\
\text { ileum }\end{array}$ & Mild active colitis \\
\hline 2 & 55 & M & $\begin{array}{l}\text { Aphthous ulcers } \\
\text { Lt colon, rectal } \\
\text { linear ulcers }\end{array}$ & Focal active colitis \\
\hline 3 & 46 & $\mathrm{~F}$ & Normal & $\begin{array}{l}\text { Mild non-specific } \\
\text { chronic colitis }\end{array}$ \\
\hline 4 & 48 & M & $\begin{array}{l}\text { Terminal ileal } \\
\text { and right colon } \\
\text { aphthous ulcers }\end{array}$ & $\begin{array}{l}\text { Mild non-specific } \\
\text { chronic colitis }\end{array}$ \\
\hline 5 & 23 & M & $\begin{array}{l}\text { Terminal ileal } \\
\text { and rectal } \\
\text { nodularity }\end{array}$ & $\begin{array}{l}\text { Mild non-specific } \\
\text { chronic colitis }\end{array}$ \\
\hline 6 & 26 & M & $\begin{array}{c}\text { Terminal ileal } \\
\text { ulcer }\end{array}$ & Mild active colitis \\
\hline 7 & 55 & M & $\begin{array}{c}\text { Mucosal } \\
\text { erythema } \\
\text { diffuse colon }\end{array}$ & Mild active colitis \\
\hline 8 & 40 & $\mathrm{~F}$ & $\begin{array}{c}\text { Erosions } \\
\text { transverse and } \\
\text { DC } \\
\end{array}$ & Mild active colitis \\
\hline 9 & 27 & M & $\begin{array}{c}\text { Diffuse } \\
\text { aphthous ulcers }\end{array}$ & Mild active colitis \\
\hline 10 & 42 & M & $\begin{array}{l}\text { Distal rectal } \\
\text { ulcers }\end{array}$ & $\begin{array}{c}\text { Focally active } \\
\text { proctitis }\end{array}$ \\
\hline 11 & 44 & M & $\begin{array}{c}\text { Distal rectal } \\
\text { erythema }\end{array}$ & $\begin{array}{l}\text { Mild non-specific } \\
\text { chronic colitis }\end{array}$ \\
\hline 12 & 41 & M & Normal & $\begin{array}{l}\text { Mild non-specific } \\
\text { chronic colitis }\end{array}$ \\
\hline 13 & 50 & M & $\begin{array}{c}\text { Anal canal } \\
\text { erythematous } \\
\text { spots } \\
\end{array}$ & $\begin{array}{l}\text { Mild non-specific } \\
\text { proctitis }\end{array}$ \\
\hline 14 & 35 & M & $\begin{array}{l}\text { Aphthous ulcers } \\
\text { diffuse colon }\end{array}$ & $\begin{array}{l}\text { Mild chronic } \\
\text { colitis }\end{array}$ \\
\hline 15 & 48 & $\mathrm{~F}$ & $\begin{array}{c}\text { Aphthous ulcer } \\
\text { TC }\end{array}$ & $\begin{array}{l}\text { Mild non-specific } \\
\text { chronic colitis }\end{array}$ \\
\hline 16 & 19 & M & $\begin{array}{c}\text { Rectal } \\
\text { hyperaemia }\end{array}$ & $\begin{array}{l}\text { Mild chronic } \\
\text { proctitis }\end{array}$ \\
\hline 17 & 53 & M & $\begin{array}{c}\text { Caecal solitary } \\
\text { ulcer }\end{array}$ & $\begin{array}{l}\text { Moderate non- } \\
\text { specific colitis }\end{array}$ \\
\hline 18 & 60 & M & $\begin{array}{l}\text { Erythematous } \\
\text { mucosa AC, TC }\end{array}$ & Focal active colitis \\
\hline 19 & 60 & M & $\begin{array}{l}\text { Terminal ileal } \\
\text { erosions }\end{array}$ & $\begin{array}{c}\text { Active chronic } \\
\text { ileitis } \\
\end{array}$ \\
\hline 20 & 37 & M & $\begin{array}{c}\text { Terminal ileal } \\
\text { ulcers }\end{array}$ & Mild active ileitis \\
\hline 21 & 60 & $\mathrm{~F}$ & Ileal ulcer & Mild chronic ileitis \\
\hline 22 & 48 & $\mathrm{M}$ & Ileal nodularity & Mild chronic ileitis \\
\hline 23 & 50 & M & $\begin{array}{l}\text { Terminal ileal } \\
\text { erythema }\end{array}$ & Mild active ileitis \\
\hline 24 & 40 & $\mathrm{~F}$ & $\begin{array}{l}\text { Aphthous ulcers } \\
\text { rectum }\end{array}$ & Active proctitis \\
\hline 25 & 40 & $\mathrm{~F}$ & $\begin{array}{l}\text { Terminal ileal } \\
\text { ulcers }\end{array}$ & Mild active ileitis \\
\hline
\end{tabular}




\begin{tabular}{|c|c|c|c|c|}
\hline 26 & 24 & F & $\begin{array}{c}\text { Aphthous ulcers } \\
\text { DC, rectal } \\
\text { erosions }\end{array}$ & $\begin{array}{c}\text { Mild active } \\
\text { proctitis, mild } \\
\text { non-specific } \\
\text { chronic colitis }\end{array}$ \\
\hline 27 & 35 & M & $\begin{array}{c}\text { Terminal ileal } \\
\text { and caecal } \\
\text { erosions }\end{array}$ & Focal active colitis \\
\hline 28 & 20 & M & $\begin{array}{c}\text { Caecal } \\
\text { erythema, ileal } \\
\text { nodularity }\end{array}$ & $\begin{array}{c}\text { Mild active } \\
\text { chronic colitis, } \\
\text { chronic ileitis }\end{array}$ \\
\hline 29 & 50 & M & $\begin{array}{c}\text { Rectal erythema } \\
\text { chronic proctitis }\end{array}$ & $\begin{array}{c}\text { Mild non-specific } \\
\text { chre }\end{array}$ \\
\hline 30 & 45 & F & $\begin{array}{c}\text { Rectal and ileal } \\
\text { ulcers }\end{array}$ & Focal active ileitis \\
\hline 31 & 24 & F & Ileal erosions & Mild active ileitis \\
\hline \multicolumn{4}{|c|}{ Table 1: Colonoscopic and Histopathological } \\
Findings of the 31 Patients in Our Study
\end{tabular}

\section{DISCUSSION}

The study was done to follow up the natural course of patients presenting with non alarming signs of bowel disease with colonoscopic findings of random or isolated ileal or colonic ulcerations and non-specific colitis on histopathology. The entire included patients were in the age group 18 to $60 \mathrm{yrs}$. without significant co morbidities and without recent NSAID intake. We found that 63.3 per cent of the patients were asymptomatic during a mean follow up period of 39 months. Capsule endoscopy studies have reported small-bowel mucosal breaks in $5 \%$ to $17 \%$ of healthy subjects. ${ }^{1-4}$ the reason to worry for the treating physician is that one of the earliest manifestations of Crohn's disease is aphthous ulcerations of the colon and ileum. Typical Crohn's disease can develop in patients with aphthous type Crohn's disease. ${ }^{5-7}$ over a variable period of time.

The hallmark of Crohn's disease is focal inflammation of the intestine which is evident as focal crypt inflammation, focal areas of marked chronic inflammation and the presence of aphthae and ulcers on a background of little or no chronic inflammation. Because of the long delay between the onset of symptoms and diagnosis, it is not easy to observe the evolution of Crohn's disease. The natural history of recurrent Crohn's disease after surgical resection has offered a guide to know the sequence of pathologic changes in Crohn's disease. ${ }^{8}$ Aphthous ulcers are the earliest characteristic of Crohn's disease, are minute ulcers ranging up to $3 \mathrm{~mm}$ diameter with a surrounding halo of erythema. Aphthae in the colon occur without an endoscopically visible central erosion and may be associated with lymphoepithelial complexes. The aphthous ulcers represent areas of immune activation.

Granulomas which are highly characteristic of Crohn's disease are neither unique to the disease nor are universally found. ${ }^{9}$ Granulomas have been found in 15 per cent of endoscopic series to up to 70 per cent in surgical series. ${ }^{10}$ Granulomas can be found in uninvolved areas of the intestine and in mesenteric lymph nodes. Typical granulomas of Crohn's disease are sarcoid-like, consisting of collections of epithelioid histiocytes and a mixture of inflammatory cells including eosinophils and lymphocytes with occasional giant cells. The granulomas in Crohn's disease are sparse, scattered and poorly formed without any areas of necrosis.

The later findings in Crohn's disease show localized architectural distortion without evidence of inflammation. When the disease becomes chronic, small aphthae can coalesce into larger stellate ulcers. Linear ulcers occur when there is longitudinal fusion of multiple ulcers. Other late features include presence of large ulcers, sinus tracts and strictures. Crohn's disease usually involves the distal small intestine and proximal colon. The clinical presentation varies considerably depending on the location of disease, intensity of inflammation and presence of complications. Those patients with mild disease, long standing symptoms and atypical disease are more likely to experience a delay in diagnosis of over a year. Presence of prodromal period may also contribute to delay in diagnosis. ${ }^{11}$ Subtle radiological and endoscopic findings preclude definitive diagnosis even among patients with typical disease.

Typical presenting features of Crohn's disease are with small bowel obstruction precipitated by indigestible foods such as raw vegetables and fruits. Long standing subclinical inflammation can progress to fibrotic stenosis with subsequent intense colicky abdominal pain accompanied by nausea and vomiting. Patients with active inflammation present with anorexia, loose or frequent stools and loss of weight. Non-specific colitis strictly speaking is a misnomer which refers to the histologic interpretation of an underlying colonic inflammation that has no characteristic qualitative and/or quantitative features to be properly classified as a specific form of acute or, usually, chronic colitis. Either the pathologist has not found a specific cellular infiltrate or any characteristic changes in the gland architecture or epithelial cells that can be helpful in classifying the inflammation or alternatively, despite adequate information the pathologist is unable to identify a specific form of colitis. ${ }^{12}$

When analysing a pathological report of non-specific colitis, the clinician needs to keep in mind the demographics, recent medications and treatment, co-morbidities of the patient, reactions to medicines, prior surgical procedures etc. History of allergies, asthma, chronic NSAID use, laxatives, autoimmune diseases, congestive cardiac failure, chronic liver disease, smoking, alcohol abuse and history of IBS are very relevant when interpreting histology of non-specific colitis. A family history of inflammatory bowel disease and celiac disease are also important in this regard. ${ }^{12}$

Irritable bowel syndrome is the most common cause of non-specific inflammation. Microscopic colitis has characterized histological features in colonic epithelium and lamina propria but sometimes inadequate samples and incorrect interpretation may hinder a diagnosis of microscopic colitis. Celiac disease if untreated can produce histological features similar to microscopic colitis. ${ }^{13}$ and celiac disease might be occasionally associated with non-specific histology. Though symptoms are not related to colonic involvement, a gluten free diet may be expected to normalize the histology in these patients.

Colon can also be involved microscopically and nonspecifically in autoimmune diseases especially those with extra intestinal involvement. This often occurs as a result of the disease or its treatment but it usually does not have any long term implications. ${ }^{12}$ Random biopsies taken during late restorative phase of infective colitis might be having only nonspecific features without any pointers to the cause of infection. ${ }^{14}$

So while interpreting as non-specific colitis, it is prudent to look for features of chronic colitis which cannot be interpreted by the medical history of the patient. It is always 
better for the pathologist to label as non characteristic of the disease rather than reporting as non-disease. In our study the majority of patients with gastrointestinal symptoms and absent red flags who had colonic and ileal ulcers, histologically reported as non-specific colitis on index biopsies had a favourable outcome without any critical events.

Chang ET al.15 reported the significance of isolated terminal ileal ulcerations in asymptomatic individuals and showed that most of them resolved without any treatment. This is a small pilot study aimed to understand the significance of ileal or colonic ulcerations so that appropriate management decisions can be instituted. It also highlights that a good histological assessment of these colonic and ileal ulceration is necessary and that the diagnosis of non-specific chronic or focal active colitis is considered only after excluding the possibility of inflammatory bowel disease and tuberculosis. This is supported by the fact that none of the patients in the study developed IBD on follow up. A larger sample population with longer duration of follow up would throw more light regarding the natural history of these ileal and colonic ulcerations.

\section{CONCLUSION}

Majority of the patients with non alarming lower gastrointestinal symptoms with histologic evidence of nonspecific colitis in patients who had colonoscopic evidence of ileal or colonic ulcerations resolved without evolution to inflammatory bowel disease on follow up. The histological diagnosis of non-specific chronic/focal active colitis is an infrequent diagnosis and must be made only after carefully excluding the possibility of IBD/ infections including tuberculosis. This will help to ensure appropriate management of these patients.

\section{REFERENCES}

1. Matsumoto T, Kudo T, Esaki M, et al. Prevalence of nonsteroidal anti-inflammatory drug-induced enteropathy determined by double-balloon endoscopy: a Japanese multicenter study. Scand J Gastroenterol 2008;43(4):490-6.

2. Goldstein JL, Eisen GM, Lewis B, et al. Video capsule endoscopy to prospectively assess small bowel injury with celecoxib, naproxen plus omeprazole, and placebo. Clin Gastroenterol Hepatol 2005;3(2):133-41.
3. Graham DY, Opekun AR, Willingham FF, et al. Visible small-intestinalmucosal injury in chronic NSAID users. Clin Gastroenterol Hepatol 2005;3(1):55-9.

4. Sidhu R, Sanders DS, McAlindon ME, et al. Capsule endoscopy for the evaluation of nonsteroidal antiinflammatory drug-induced enteropathy: United Kingdom pilot data. Gastrointest Endosc 2006;64(6):1035.

5. Matsumoto T, Iida M, Nakamura S, et al. Cohn's disease of aphthous type: serial changes in intestinal lesions. $\mathrm{Br} \mathrm{J}$ Radiol 2000;73(874):1046-51.

6. Hizawa K, lida M, Kohrogi N, et al. Crohn disease: early recognition and progress of aphthous lesions. Radiology 1994;190(2):451-4.

7. Ni XY, Goldberg HI. Aphthoid ulcers in crohn disease: radiographic course and relationship to bowel appearance. Radiology 1986;158(3):589-96.

8. Rutgeerts P, Geboes K, Vantrappen G, et al. Natural history of recurrent crohn's disease at the ileocolonic anastomosis after curative surgery. Gut 1984;25(6):66572.

9. Chambers TJ, Morson BC. The granuloma in crohn's disease. Gut 1984;25:665-72.

10. Riddell RH. Pathology of idiopathic inflammatory bowel disease. In: Kirsner JB, ed. Inflammatory bowel disease, Philadelphia: Saunders WB, 2000;427-52.

11. Burgmann T, Clara I, Graff L, et al. The manitoba inflammatory bowel disease cohort study: prolonged symptoms before diagnosis-how much is irritable bowel syndrome? Clin Gastroenterol Hepatol 2006;4(5):614-20.

12. Mantzaris GJ. What is the natural history of a patient with non-specific colitis on large bowel histology? Annals of Gastroenterol 2005;18(2):116-8.

13. Whitehead R. Mucosal biopsy of the gastrointestinal tract. Chapter 17. Other forms of colitis. Saunders WB, 1990;p 364.

14. Mantzaris GJ, Hatzis A, Archavlis E, et al. The role of colonoscopy in the differential diagnosis of acute severe hemorrhagic colitis. Endoscopy 1995;27(9):645-53.

15. Hye-Sook Chang, Don Lee, Jong Cheol Kim, et al. Isolated terminal ileal ulcerations in asymptomatic individuals: natural course and clinical significance. Gastrointest Endosc 2010;72(6):1226-32. 